\title{
GENETIC ANALYSIS OF ENZYME POLYMORPHISMS IN HERRING (CLUPEA HARENGUS L.)
}

\author{
D. P. F. KING \\ Department of Agriculture for Northern Ireland, Fisheries Research Laboratory, \\ 38 Castleroe Road, Coleraine, Co Londonderry, Northern Ireland
}

Received 1.viii.83

\section{SUMMARY}

Single pair matings were performed to confirm the genetic basis of electrophoretic variants of several enzyme systems in north-east Atlantic herring (Clupea harengus) collected in spawning condition from the North Irish Sea. Mendelian inheritance of codominant autosomal alleles was established for Aat-2, Idh-2, $L d h-2$ and Pgi. Crosses among Fum-1,Idh-1 and Sod homozygotes produced only homozygous offspring.

This study also permitted the investigation of linkage relationships between polymorphic loci. Linkage was not observed between any two loci in the 13 pairwise comparisons made. This analysis constituted the first investigation of linkage relationships in the species.

\section{INTRODUCTION}

Since the protein composition of an organism reflects the primary product of structural genes, electrophoretic separation of proteins has proved a valuable tool in the differentiation of morphologically similar sibling species and in the detection of geographical species variation (Utter et al., 1974; Ferguson, 1980). However, the utilisation of this technique relies on the ability to ascribe a precise genetic basis to the observed electrophoretic variation among individuals (Allendorf and Utter, 1979). Since most marine fish cannot easily be bred and reared in captivity the assumption of Mendelian inheritance has been mainly validated by criteria such as repeatability, similarity to known genetic variants in other species, and conformance of phenotypic frequencies to Hardy-Weinberg distributions. However, variation in protein expression from a given tissue reflecting other than genetic differences among individuals may be caused by a series of factors e.g., changes resulting from extraction procedures and storage period (Allendorf and Utter, op. cit.). Furthermore, Fairbairn and Roff (1980), demonstrated the low power of the $\chi^{2}$-test and the Hardy-Weinberg distribution, particularly when applied to small sample sizes, to detect deviations from basis genetic models of inheritance. Thus, while adherence to the above mentioned criteria is usually sufficient for verification of Mendelian variants, ultimate proof is only obtainable from breeding studies (Allendorf and Utter, 1979).

The ability to comprehend and predict the effects of such genetic phenomena as segregation and recombination is central to a proper understanding of the population genetics of a species (Hartl, 1980). Thus although the primary purpose of this inheritance study was verification of the genetic basis of observed polymorphism, crosses were also selected, wherever possible, to facilitate linkage analysis. 
Although a variety of polymorphic enzymes exist in the herring, Clupea harengus L., because of the technical problems associated with the breeding and rearing of this species in captivity, to date only one attempt has been made to study the formal genetics of this species (Kornfield et al., 1981). The present study complements and extends the findings of that investigation and examines linkage relationships in 13 pairwise comparisons of 4 enzyme loci.

\section{Materials ANd Methods}

\section{(i) Matings}

Herring in spawning condition were collected by means of gill net fishing at 21.30 hours on 21 September, 1981, $\frac{1}{2}$ mile north-east of Kilkeel, Co Down, N Ireland $\left(54^{\circ} 22^{\prime} \mathrm{N} ; 5^{\circ} 55^{\prime} \mathrm{W}\right)$. The freshly culled herring were rapidly transferred to an insulated container, taken ashore and transported at $4^{\circ} \mathrm{C}$ some 30 miles by road to the Queen's University of Belfast, Marine Biology Station, Portaferry. Some 4 hours after the fish had been caught and killed, single pair artificial matings were performed. The eggs were stripped from the female fish into incubator boxes that were submerged in shallow plastic trays filled with filtered sea water. Each incubator box, or cell was made from a plastic lunch box that had its base and detachable lid formed from $50 \mu \mathrm{l}$ nylon gauze. Milt from a ripe male was extruded and mixed with the sea water over the eggs. Five minutes was allowed for the fertilisation of the eggs before the incubator cell was removed from its holding tray and submerged in a constant flow water-table. Temperature was maintained at $13^{\circ} \mathrm{C} \pm 1^{\circ}$ during the course of the experiment. Excellent success in hatching eggs and rearing the larvae to yolk-sac absorption was achieved with this method.

After yolk-sac absorption individual larvae were rinsed in distilled water to remove external salts, blotted of adhesive water and transferred to $5 \mathrm{~mm}$ squares of Whatman's No. 3 filter paper, and crushed and soaked into the paper together with $10 \mu \mathrm{l}$ of ice cold extracting buffer $(0.01 \mathrm{M}$ Tris-HCL,

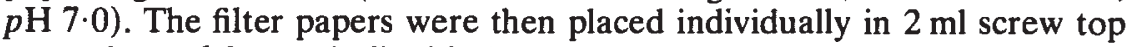
ampoules and frozen in liquid nitrogen.

As it was not possible to retain for electrophoretic screening the progeny from all matings it was decided to freeze only those progeny from informative crosses and thereby maximise the return of information from the study. Although fertilisation had been initiated without prior knowledge of the parental genotypes, rapid assaying of tissue dissected from the parents of each mating enabled the selection of progeny of informative crosses. Thus, 200-300 progeny from 14 crosses were retained; however, as not all adult allozymes were resolved in the larvae, a much smaller body of data using 6 crosses are presented in this study.

Liver and skeletal muscle tissues dissected from parents were homogenised for $10 \mathrm{sec}$ in an equal volume of $0.01 \mathrm{M}$ Tris-HCL, $p \mathrm{H} \mathrm{7.0.}$ Samples were centrifuged at $5000 \mathrm{~g}$ and the supernatants used for electrophoresis.

\section{(ii) Electrophoretic procedures}

Larvae and adult tissue extracts were subjected to horizontal starch gel electrophoresis using the method described by Ferguson (1980). Two buffer 
systems were used to resolve banding patterns:

(a) gel buffer: 0.076 M Tris, 0.005 $\mathrm{M}$ citric acid, 0.015 boric acid and 0.05 lithium hydroxide $p \mathrm{H} 8.6$; electrode buffer: $0.3 \mathrm{M}$ Boric acid, $0 \cdot 1 \mathrm{M}$ lithium hydroxide $p \mathrm{H} 8.6$ (Ferguson, 1980).

(b) gel buffer: $0.002 \mathrm{M}$ citric acid, $\mathrm{pH} 6.9$; electrode buffer: $0.04 \mathrm{M}$ citric acid, $p \mathrm{H} 6.9$ (Clayton and Tretiak, 1972). Both buffers were $p \mathrm{H}$ adjusted with $\mathrm{N}$-(3-aminopropyl)-diethanolamine.

Visualisation of enzyme banding patterns, after electrophoresis was accomplished using the staining assays described by Siciliano and Shaw (1976).

The system of locus and allele nomenclature suggested by Allendorf and Utter (1979) was used. An abbreviation represents each enzyme and when italicised refers to the locus coding for that enzyme. Hyphenated numerals refer to multiple loci, numbered from most cathodal to most anodal. Allelic variants at a particular locus are designated by their mobilities relative to that of the common allele, which was designated 100 . A variant allele producing a product that migrates cathodally from the origin is preceded by a hyphen. Notations of enzyme subunit structure are based on Darnall and Klotz (1975). Table 1 lists the enzymes assayed, number of loci scored in each case and the most appropriate adult tissue and buffer systems for optimum electrophoretic resolution.

\section{(iii) Nomenclature and statistical treatment of segregation data}

For simplicity of notation and in order to be consistent with the reporting of segregation data for other fish species (e.g., May et al., 1979; Taggart 1981) the mobility defined alleles at the two loci being investigated for joint segregation were redesignated in the classical form $A, A^{1}, B$ and $B^{1}$. Similarly, in single locus segregation analysis mobility defined alleles were redefined in this more conventional genetic nomenclature.

The joint segregation test criterion, $\chi_{A B}^{2}$ (Mather, 1951), was used to test each pairwise comparison for departure from independent assortment. The symbols and statistics used were as follows:

TABLE 1

Enzymes examined, structure, abbreviations, number of loci, Enzyme Commission (E.C.) number and conditions for best electrophoretic results

\begin{tabular}{lllllll}
\hline \multicolumn{1}{c}{ Enzyme } & E.C. No. & $\begin{array}{c}\text { Subunit } \\
\text { structure }\end{array}$ & Acronym & $\begin{array}{c}\text { No. of } \\
\text { loci }\end{array}$ & $\begin{array}{c}\text { Adult* } \\
\text { tissue }\end{array}$ & $\begin{array}{c}\text { Buffer } \\
\text { system }\end{array}$ \\
\hline Aspartate aminotransferase & 2.6 .1 .1 & Dimer & AAT & 2 & M & 2 \\
Esterase & 3.1 .1 .1 & Monomer & EST & 4 & L & 1 \\
Fumerase & 4.2 .1 .2 & Tetramer & FUM & 2 & M & 1 \\
Isocitrate dehydrogenase & 1.1 .1 .42 & Dimer & IDH & 2 & L & 2 \\
Lactate dehydrogenase & 1.1 .1 .27 & Tetramer & LDH & 2 & M & 1 \\
Phosphogluoisomerase & 5.3 .1 .9 & Dimer & PGI & 1 & M & 1 \\
Phosphoglucomutase & 2.7 .5 .1 & Monomer & PGM & 2 & L & 1 \\
Superoxide dismutase & 1.15 .1 .1 & Dimer & SOD & 1 & L & 1 \\
\hline
\end{tabular}

* Tissues: M, skeletal muscle; L, liver.

$\ddagger$ Buffer systems corresponding to symbols are described in text.

$a_{1}=$ observed $A A B B$ progeny for both testcross $\left(A A B B \times A A^{1} B B^{1}\right)$ and single backcross $\left(A A^{1} B B \times A A^{1} B B^{1}\right)$ matings 
$a_{2}=$ observed $A A B B^{1}$ progeny for both testcross and single backcross matings

$a_{3}=$ observed $A A^{1} B B$ for testcross progeny and $A^{1} A^{1} B B$ for single backcross progeny

$a_{4}=$ observed $A A^{1} B B^{1}$ for testcross progeny and $A^{1} A^{1} B B^{1}$ for single backcross progeny

$N=$ total informative progeny $=a_{1}+a_{2}+a_{3}+a_{4}$

$\chi_{A B}^{2}=$ chi-square test statistic for departure from independent assortment of the two loci $=\left(a_{1}-a_{2}-a_{3}+a_{4}\right)^{2} / N$, with $\mathrm{df}=1$

$r=$ recombination fractions (assuming the largest class, $\left(a_{1}+a_{4}\right)$ or $\left(a_{2}+\right.$ $a_{3}$ ) represents the parental genotypes when linkage phase is unknown $=\left(a_{2}+a_{3}\right) / N$ or $\left(a_{2}+a_{4}\right) / N$ respectively

s.e. $=$ standard error of the recombination fraction $r$ calculated as $\sqrt{r(1-r) / N}$

Conventional $\chi^{2}$-tests for departure from $1: 1$ segregation with $\mathrm{df}=1$ or $1: 2: 1$ segregation with $\mathrm{df}=2$ were used in single locus segregation analysis. For joint segregation analysis the lowest informative sample size was 39 progeny. This was from a single backcross mating where it was necessary to exclude the non-informative heterozygous progeny $\left(A A^{1}\right)$ at the locus for which both parents were heterozygous (May et al., 1979). This constituted approximately 50 per cent of the total sample size. The informative sample size for testcross matings were larger and ranged for 66 to 93 .

\section{RESUltS}

\section{(i) Larval electrophoretic pattern}

Activity for all enzymes in larval tissue extracts could be demonstrated by using a combination of prolonged incubation and increased amounts of substrate. The resolution of some enzymes, however, e.g., PGM, was too poor to permit reliable scoring. Furthermore, several of the isozymes present in the adults did not appear to be activated in the larval stages. Although a detailed explanation of adult banding patterns have previously been given by several authors (e.g., Andersson et al., 1981; King, 1983), the following description of typical larval zymograms and the number of loci activated in larvae for polymorphic enzymes should prove useful to future investigations of electrophoretic variation in larval herring.

AAT-Only Aat-2 was visible on gels stained for AAT. However electrophoresis of larger larvae (i.e., 3-4 week old Mourne herring larvae taken from the plankton demonstrated that the additional cathodal mitochrondrial Aat-1 isozyme, (primarily expressed in skeletal muscle and heart tissue in adult fish) had been activated (King, 1983).

EST-Enzyme activity was also exhibited on gels stained for esterase, but only the monomorphic zone 1 was clearly expressed in the larval stage. Est-4 was expressed as a faint diffuse streak in the tissue extracts of larger larvae (King, op. cit.). 
FUM-One zone of activity appearing as a diffuse band was resolved for fumarase. The gel position of this band approximated that of the slower migrating zone (Fum-1), primarily expressed in the skeletal muscle tissue of adults (King, op. cit.). The more anodal zone, strongly expressed in adult skeletal muscle and eye extracts, failed to show activity in larval gels.

IDH-The products of $I d h-1$ and the more anodally migrating cytoplasmic locus $I d h-2$, which predominate in skeletal muscle and liver tissue of adult fish respectively, were both present in larval tissue extracts. Furthermore, as in the electrophoretic patterns of adults, larval IDH zymograms did not exhibit an interlocus heterodimeric isozyme.

LDH-The $L d h-1$ homotetrameric isozyme which is most active in white muscle in adult fish, was not detected in freshly hatched larvae or in the tissue extracts of larger larvae. However, the interlocus heterotetrameric band was strongly expressed in all larval zymograms.

PGM-A combination of weak staining and diffuse banding prevented interpretation of zymograms for PGM in freshly hatched larvae. However, activity for Pgm-1, expressed primarily in skeletal muscle, was observed for the larger larvae with an increased amount of substrate and on prolonged staining (King, op. cit.). In the present study the more anodal Pgm-2 liver isozyme (Lush, 1969) yielded little or no activity in either adult or larval tissue extracts.

The electrophoretic expression of PGI and SOD in larval specimens paralleled that described for adult tissue (Andersson et al., 1981; King 1983) and were both clearly expressed at this stage of development.

\section{(ii) Segregation analysis}

\section{(a) Single locus segregation}

The single locus segregation statistics for Mourne herring are presented in table 2. No significant deviation from Mendelian expectations were observed with all loci segregating in conformance with the expected $1: 1$ or $1: 2: 1$ proportions (table 3 ). There is, however, some dubiety surrounding these results in that a small number of unexpected progeny types occurred in 3 of the matings (enclosed in brackets in table 2) and two of these involved the Pgi locus.

No suitable matings were performed to examine the Mendelian inheritance of Fum-1, Idh-1 and Sod variants; however, crosses among homozygotes at these loci produced only homozygous offspring.

\section{(b) Joint segregation}

Results of 6 linkage associations involving 13 pairwise comparisons of 4 single pair artificial matings of herring are presented in table 3 . As the results from single locus segregation analysis have already been presented (table 2) only joint segregation statistics are given here. The distribution for all 13 pairwise comparisons does not differ significantly from the $1: 1: 1: 1$ ratio expected for unlinked loci. Calculations of the recombination fraction $(r)$ indicates that all loci examined undergo recombination at a frequency of approximately 50 per cent. These data are not significantly different from random assortment of co-dominant alleles at unlinked loci. 


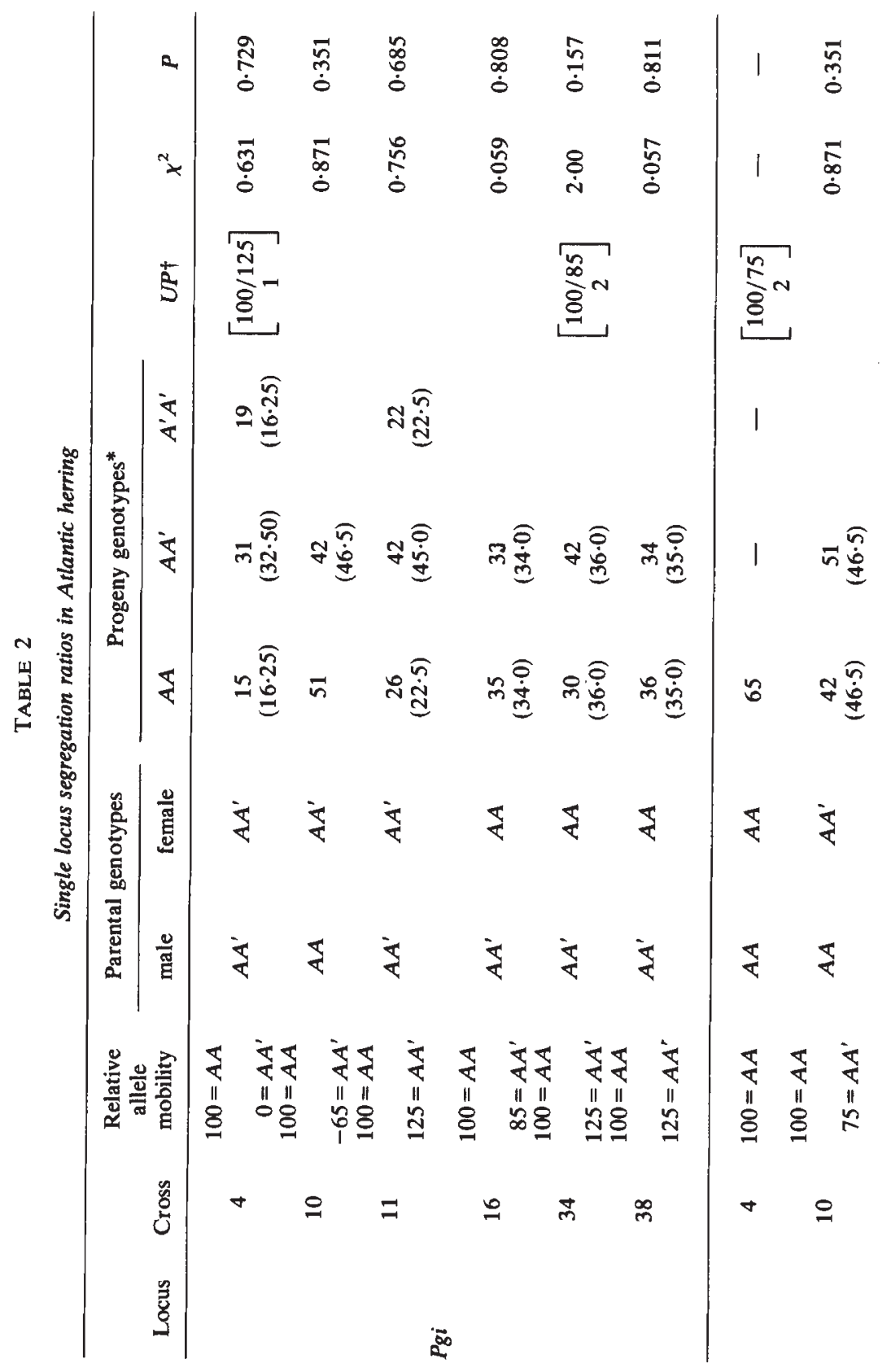




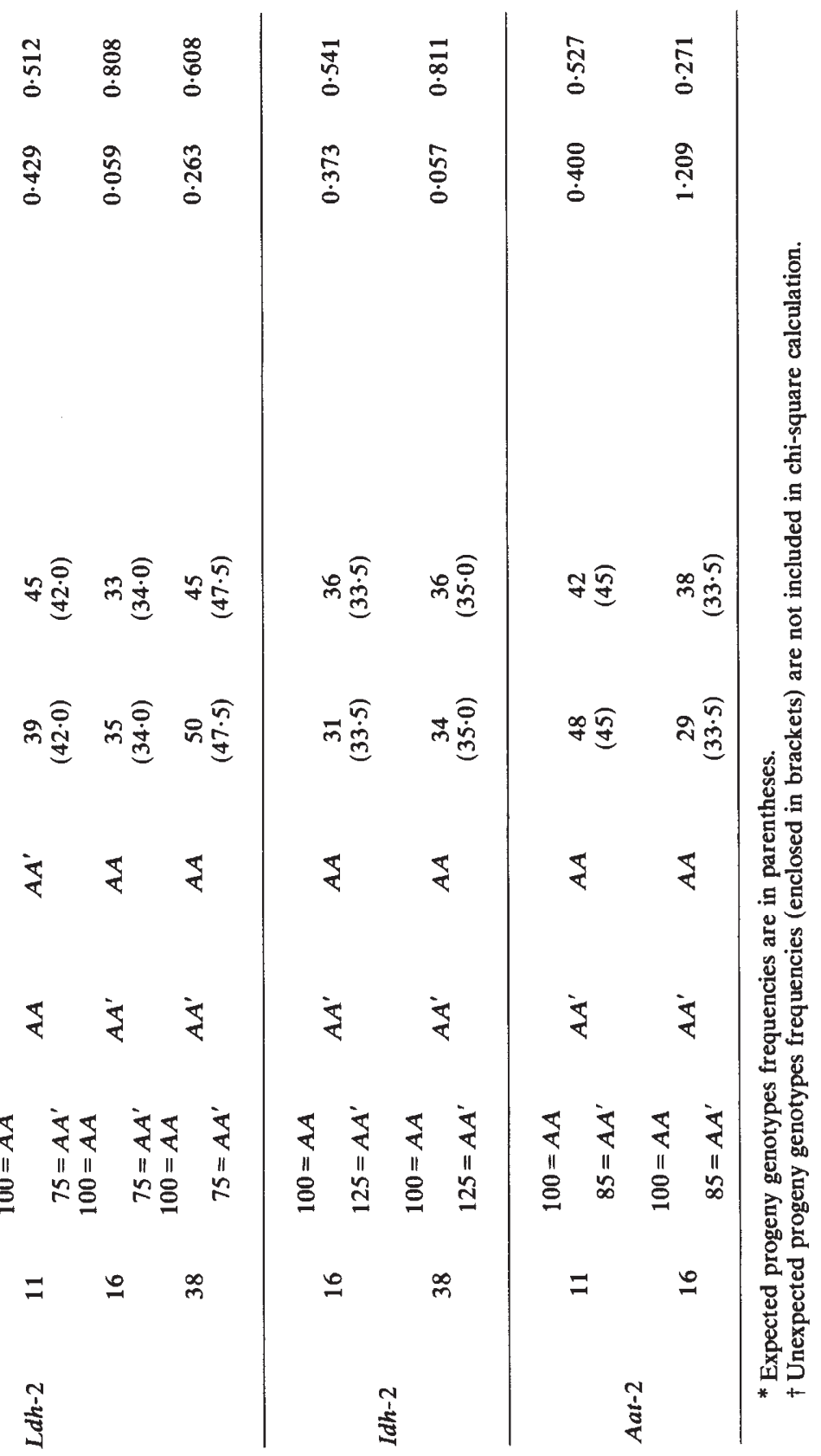




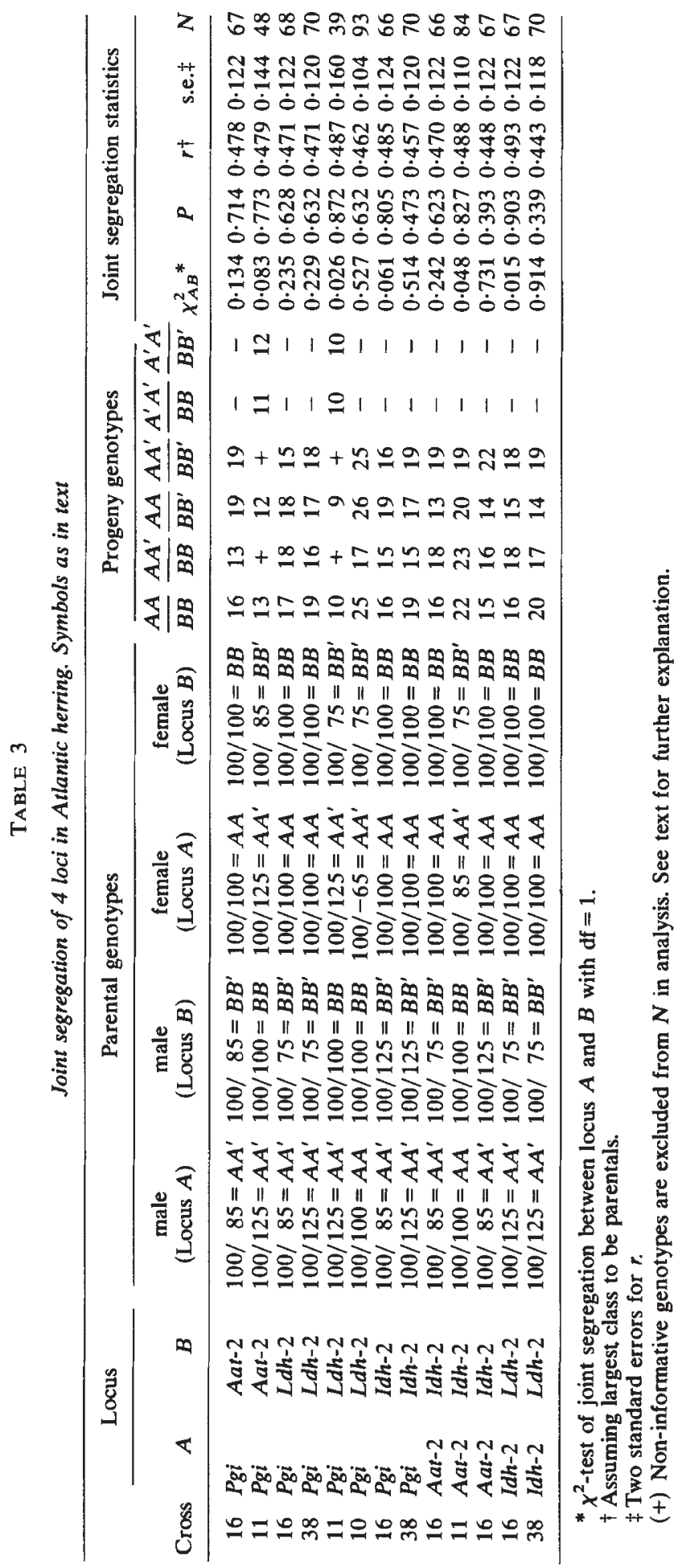




\section{Discussion}

Kornfield et al., (1981), in their study of inheritance of allozymes in North West Atlantic herring, reported the zymograms of some dimeric and tetrameric enzymes to exhibit a reduced number of isozymes between loci and concluded that there must have been considerable evolutionary divergence in structure or composition of component loci for these enzymes. The results of this investigation agree with their findings for malic enzyme and isocitrate dehydrogenase and, accordingly, would support their suggestion on the evolutionary divergence of their respective isozymes. Kornfield et al., (1981) observed a general absence of the heterotetrameric isozyme between $L d h-1$ and $L d h-2$ homozygotes and suggested this may have resulted from restricted subunit assembly as indeed, is the case in other fish species, (Whitt and Horowitz, 1970). In contrast to the American study, however, the LDH heteropolymer was always strongly expressed in this investigation. Thus, it would seem that the previous findings were probably a function of electrophoretic running conditions (possibly the different buffer system used) and were not related to enzyme subunit assembly as had been suggested.

Several of the isozymes active in adult fish were not expressed in larvae e.g. Aat-1, $L d h-1$, which may indicate that these enzyme loci are not activated at this stage of development. Alternatively, there may be insufficient enzyme present in freshly hatched larvae for its activity to be detected by electrophoresis coupled with specific histochemical staining. The latter would seem the case for LDH where the heteropolymer was clearly expressed in the larvae, but the $L d h-1$ isozyme was not detectable at this stage of development. Possible ontogenetic changes have also been reported for several other fish species. Dando (1974), observed little Pgi-1 or Pgi-2 (his GPI-B and GPI-A respectively) activity in newly hatched plaice, Pleuronectes platessa L., and flounder, Platichthys flesus L., larvae compared to the strong expression of the Pgi-1 isozyme exhibited by juvenile and adult fish. Similarly, Smith (1976) reported a reduced number of PGM and PGI isozymes in the larvae of the Atlantic mackerel, Scomber scombrus L., and Jørstad et al., (1980) also observed a reduction in the banding patterns of several isozymes in the early pelagic stages of Atlantic Cod, Gadus morhua L. It is premature to conclude anything from these observations but clearly this could be a fruitful area for further investigation.

The results of this study and those of Kornfield et al., (1980), seem to confirm that inheritance of those allozymes tested are under Mendelian control. The occurrence of the small numbers of unexpected progeny types are not easy to explain. Similar reports of exceptional progeny types occurring in some particular matings have been made by several investigations involved in studies of the inheritance of biochemical variation in fish (e.g. Clayton et al., 1975 Purdom et al., 1976 and Wright et al., 1980). May (1980), in his review on the inheritance of biochemical loci in salmonids, suggests that anomalous progeny types may be the result of strays between hatchery cells, sample contamination or such genetic phenomena as aneuploidy intragenic recombination or residual tetrasomy. The latter is of particular relevance to salmonids because it presents incomplete diploidy in the extant salmonid genome (May, 1980).

The unexpected genotypes that appeared in particular matings in this study were present in the pool of parental fish and did not involve new 
allele types. This, together with the fact that no unexpected progeny types were reported by Kornfield et al., (1981), in the previous study on the inheritance of the same loci in the North West Atlantic herring, might suggest that the anomalies were the result of contamination. If indeed, this was the case, the low chi-square values with non-significant probabilities for all the crosses would seem to indicate that contamination was minimal. However, it is obvious that it will be necessary to pay careful attention to such crosses in the future.

Linkage was not observed between any two loci in the 13 pairwise comparisons made. This is not unexpected, given that Clupea harengus has a haploid complement of 26 chromosomes (Gold et al., 1980) and, accordingly, the probability of establishing linkage is low amongst the random loci. Obviously, too few comparisons have been made to draw significant conclusions on linkage in this species and a great deal of research remains to be done with many more pairwise comparisons yet to be examined. Nevertheless, it is hoped that the success obtained in the present study will provide a platform from which to base future studies of segregation of biochemical loci in this species.

Attempts at studying genetic variability in marine fish populations are of ten hampered by problems related to heterogenity of age groups, migration and possible differential survival before fish are sampled in the spawning population (Jørstad et al., 1980), Jamieson (1974) suggested the use of biochemical analysis or early larval stages as a means of obtaining more precise information on stock structure of the spawning population. However, the applicability of electrophoretic techniques as a tool for larval stock identification has been restricted because of technical problems. Thus, the success in applying the techniques of gel-electrophoresis to the early larval stages of herring, should provide new opportunities to investigate the complex population structure of this important commercial species.

\section{REFERENCES}

AllendORF, F. W. AND UTTER, F. M. 1979. Population genetics. In Hoar, W. S., Randall, D. J. and Brett, J. R. (eds.) Fish Physiology, vol. VIII, Academic Press, London, pp. 407-454.

ANDERSSON. L., RYMAN, N., ROSENBERG, R. AND STAHL, G. 1981. Genetic variability in Atlantic herring (Clupea harengus harengus); description of protein loci and population data. Hereditas, 95, 69-78.

CLAYTON, J. W. AND TRETIAK, D. N. 1972. Amine-citrate buffer for $p H$ control in starch gel electrophoresis. J. Fish. Res. Bd. Can., 29, 1169-1172.

DANDO, P. R. 1974. Distribution of multiple glucosephosphate isomerases in teleostean fishes. Comp. Biochem. Physiol., 47, 663-679.

DARNALL, D. W. AND KLOTZ, I. M. 1975. Subunit constitutions of proteins: A table. Arch. Biochem. Biophys., 166, 651-682.

FAIRBAIRN, D. J. AND ROFF, D. A. 1980. Testing genetic models of isozyme variability without breeding data: Can we depend on the $\chi^{2}$ ? Can. J. Fish. Aquat. Sci., 37.

FERGUSON, A. 1980. Biochemical Systematics and Evolution. Blackie, Glasgow.

GOLD, J. R., KAREL, W. J. AND STRAND, M. R. 1980. Chromosome formulae of North American fishes. Prog. Fish Cult. 42, 10-23.

HARTL. D. L. 1980. Principles of Population Genetics. Sinauer Associates, Massachusetts.

JAMIESON, A. 1974. Genetic tags for marine fish. In Harden Jones, F. R. (ed.) Sea Fisheries Research. Research Elk Science, London, pp. 91-99.

JøRSTAD, K. AND NAEVDAL, G. 1981. Significance of population genetics on management of herring stocks. ICES C.M. 1981/H:64, 18 pp. (mimeo). 
KING, D. P. F. 1983. Genetic and morphometric analyses of Atlantic herring (Clupea harengus L.) stocks to the west of the British Isles with particular reference to the North Irish Sea. Ph.D. Thesis, Queen's University, Belfast.

KORNFIELD, I., GAGNON, P. S. AND SIDELL, B. D. 1981. Inheritance of allozymes in Atlantic herring (Clupea harengus harengus). Can. J. Genet. Cytol., 23, 715-720.

LUSH, I. E. 1969. Polymorphism of a phosphoglucomutase isoenzyme in the herring (Clupea harengus). Comp. Biochem. Physiol., 30, 391-395.

MATHER, K. 1951. The Measurement of Linkage in Heredity. Methuen, London.

MAY, B. 1980. The salmonid genome: evolutionary restructuring following a tetraploid event. Ph.D. Thesis, The Pennsylvania State University, State College.

MAY, B., WRIGHT, J. E. AND STONEKING, M. 1979. Joint segregation of biochemical loci in Salmonidae: Results from experiments with Salvelinus and review of the literature of other species. J. Fish. Res. Board Can., 36, 1114-1128.

PURDOM, C. E., THOMPSON, D. AND DANDO, R. P. 1976. Genetic analysis of enzyme polymorphisms in plaice (Pleuronectes platessa). Heredity, 37, 193-206.

SICILIANO, M. J. AND SHAW, C. R. 1976. Separation and visualization of enzymes on gels. In Smith, I. (ed.) Chromatographic and Electrophoretic Techniques, vol. 2, Heinemann, London, pp. 185-209.

SMITH, P. J. 1976. Protein variation in the Atlantic mackerel. (Scomber scombrus L.). Ph.D. Thesis, University of East Anglia.

TAGGART, J. B. 1981. An electrophoretic study of genetic variation in Irish brown trout (Salmo trutta L.) Ph.D. Thesis, Queen's University, Belfast.

UTTER, F. M., HODGINS, H. O. AND ALLENDORF, F. W. 1974. Biochemical genetic studies of fishes: Potentialities and limitations. In Malins, D. C. and Sargent, J. R. (eds.) Biochemical and Biophysical Perspectives in Marine Biology. vol. 1, Academic Press, New York, pp. 213-238.

WHITT, G. S. AND HAROWITZ, J. J. 1970. Evolution of a retinal specific lactate dehydrogenase isozyme in teleosts. Experientia, 26, 1302-1304.

WRIGHT, J. E., MAY, B., STONEKING, M. AND LEE, G. M. 1980. Pseudolinkage of the duplicate loci for supernatant aspartate aminotransferase in brook trout, Salvelinus fontinalis. $J$. Heredity, 71, 223-228. 